\title{
住宅における電気機器の所有状況と照明・動力他用電力消費量に関する調査 QUESTIONNAIRE SURVEY ON POSSESSION OF ELECTRIC APPLIANCES AND ELECTRICITY FOR LIGHTING AND OTHERS IN HOUSEHOLD.
}

\author{
源城 かほり*, 田辺新一**, 松本真一***, 長谷川兼一****, 吉野 博***** \\ Kahori GENJO, Shin-ichi TANABE, Shin-ichi MATSUMOTO, \\ Ken-ichi HASEGAWA and Hiroshi YOSHINO
}

\begin{abstract}
A questionnaire survey on the possession of electric appliances and its influence on the energy consumption in household were conducted in 1996. It was found that the increase in the consumption of residential electricity was due to the use of higher number of electric appliances. This reflects the higher economic status of the household and their life style. The relationship between electric consumption for lighting and others and the influencing factor is evaluated by using the multi-variate analysis. The results of this study are expected to provide fundamental information in order to enhance residents' awareness of the importance of energy conservation.
\end{abstract}

Keywords: Electric appliances, Electric consumption, Lighting and others, Life style, Questionnaire survey, Multi-variate analysis 電気機器, 電力消費量, 照明・動力, ライフスタイル, アンケート調查, 数量化分析

1 はじめに

地球環境問題の解決に向けて, 各分野での一層の省エネルギーがま すます重要な課題となっているなか, 住宅用エネルギー消費量は依然 として增加の傾向にある ${ }^{1)}$ 。住宅用エネルギ一消費は用途別に, 暖房, 冷房, 給湯, 照明・動力他と分類されるが, このうち暖房用エネルギー および冷房用エネルギーに関しては，1999年 3 月の次世代省エネル ギー基準2)告示に伴う住宅の断熱気密化によって対策が進んでいると 言える。それに対して，給湯用および照明・動力他用エネルギーは， 欧米先進国に比べて同等であるか，もしくはそれを上回る消費となっ ており，それぞれ住宅用総エネルギー消費量の約 $30 \%$ つをつ占めてい る ${ }^{3)}$ 。

住宅のエネルギー消費量は, 地域の気候特性や経済状況の影響を受 け，質と量が年々変化すると言われている4)。また, 生活形態や住宅 設備の多様化・高度化によって, そのエネルギー構造は著しく変化し ている5゙。また，住宅のエネルギー消費量は世帯属性に応じて様々に 異なることも数々の調查で報告されており ${ }^{5)-9}$, 常に最新の動向を調 査することが重要である。

住宅におけるエネルギー消費量の調査・分析は, 1970 年代から日 本各地で多数行われている ${ }^{3)-17)}$ 。調查方法に基づいて分類すると, ア ンケート調査やエネルギー消費量の実測調査, 統計資料に基づく調查 等がある。先駆的なものとして, 1976年の家計調査による住宅の全国 県庁所在都市別エネルギー消費量の推計と, 1978 年の 9 都市・5 種別 の住宅約 1200 件を対象としたアンケート調査を併用した尾島らの
調査が挙げられる(10)-12)。また, 石田らは, 1985 年以降に建築され た全国 8 地域の工業化戸建住宅を対象として，1990年から 1991 年 に約 1000 件のアンケート調査を行っている ${ }^{13)}$ 。

全国を対象とした調查には，澤地らによる全国 8 都市域におけ る住宅のエネルギー消費とライフスタイルに関するアンケート調査 のほか ${ }^{14)}$ ，中上らによる家計調查等の統計資料を用いたマク口な方 向からの日本各地の住宅エネルギー消費量の調查がある ${ }^{1}$ 。また, 三浦は, 家計調査を基に，1991 年から 1995 年の 5 年間の全国の県 庁所在都市における住宅のエネルギー消費量を用途別に推計してい $3^{15)}$ 。

地域が限定されているものの，エネルギー特性を詳細に把握し たものとして，渡邊らによる福岡市における戸建および集合住宅を 対象とした 1990 年から 1992 年の 2 年間にわたる 1000 件から 2000 件のアンケート調査がある ${ }^{4)}$ 。エネルギー消費量を用途別, 機器別 に電力測定器を用いて詳細に実測した例として, 商品科学研究所に よる 1991 年から 1992 年の戸建住宅 6 件および集合住宅 10 件の調 查のほか ${ }^{7)}$, 濱田らによる札幌市の戸建住宅 9 件・集合住宅 2 件を 対象とした 1998 年からの 1 年間にわたる用途別, 機器別エネルギー 消費量の実測調査がある ${ }^{16)}$ 。

既往の調查研究をまとめると; 次のように言えよう。近年, 特に, 照明・動力他用エネルギー消費量が増加していることが問題となっ ており，その伸び率は年平均 $2.5 \%$ 以上となっている ${ }^{3)}$ 。ライフス タイルの変化に伴ったエネルギー消費機器の多様化がその原因の一

\footnotetext{
* 秋田県立大学システ公科学技術学部 助手・修士 (生活科学)

** 早稲田大学理工学部 教授・工博

*** 秋田県立大学システム科学技術学部 秋授県立大学 (学学

秋田県立大学システム科学技術学部 助教授・博士 ( 学) 
つであると考えられる ${ }^{1)}{ }^{19)-21)}$ 。照明・動力他用エネルギー消費量は， ライフスタイルの違いや世帯属性の違いに左右されるところが大き いため，その削減が難しい。また，リモコン操作のために主電源を 付けたままにする機器や多機能な機器が増え，使用しない時にも消 費する電力, いわゆる待機電力が増加している よると，待機電力が住宅全体の電力消費量に占める割合は $9 \sim 15 \%$ であることが報告されている3，7)，(16),23)-26)。待機電力が大きい機器と してビデオやオーディオコンポ，ステレオ，CD ラジカセ，衛生放送 チューナー, FAX 付電話機等が挙げられている ${ }^{7,16), 26) 。 ~}$

そこで，筆者らのうち 2 名は，照明・動力他用の電力消費量に着 目し，対応する機器の実態を明らかにすることを目的として，住宅 における電気機器の所有状況に関するアンケート調査を 1996 年に行 い, 住宅で所有されている電気機器の種類や台数，エネルギー消費

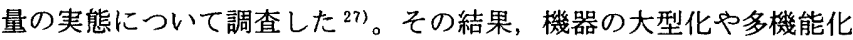
が進んでいることや，エネルギー消費量が世帯属性の一つである年

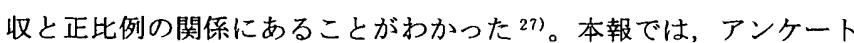
調查結果をさらに分析・考察することにより，対応する機器や消費 量に影響を及ぼす要因を明らかにし，住宅におけるエネルギー消費 量を効率よく削減するための基礎的知見を得たので報告する注。本 報では，エネルギー消費量の中でも，照明・動力他用電力消費量に 着目し，住宅におけるエネルギー消費量の実態を電気機器の所有状 況の観点から明らかにしようとしている点に特徴があり，電気機器 の容量や種類に関して詳細に調査を行っている。また, 既往の研究 では，分析の手法として重回帰分析を用いた例が多いのに対し，本 報では，従来から説明変数として用いられている住宅属性や家族属 性の他に，電気機器の所有状況に関寸る因子を加えて，数量化分析 を行っている点に特徵がある。得られた結果により，電力消費量削 減を進める必要のある機器を明らかにする。また，数量化分析にお いて偏相関係数が高かった因子を用いて，調查対象世帯の類型化を 試み, 各グループにおける照明・動力他用電力消費量と機器所有の 特徴に関して考察する。

\section{2 調査概要}

1996 年 12 月中旬から 1997 年 1 月下旬にかけて，生活価值創造住宅 開発技術研究組合注2 (通称ハウスジャパン)に参加している34社の社員 を調査対象とし、アンケート調査票を配布した。

表 1 に調查内容を示す。調査内容は，世帯属性，住居属性，電気機 器の所有状況, エネルギー消費量の 4 つに分けられる。電気機器の所 有状況に関しては, 電気機器を調理, 冷暖房, $\mathrm{AV}$ ・情報, 家事・衛生, その他の5つの用途にあらかじめ区分した上で, 表2に示すように, 各 用途に対応する代表的な電気機器を十数個挙げておき, 各機器の所有 台数を記入してもらった。表 2 に示寸機器以外に所有している機器が ある場合は空欄に記入してもらう形式とした。棆蔵庫, テレビ，洗濯 機に関しては，容量や種類を問う項目を設けた。なお，泠暖房用機器 は本来ならば照明・動力他の用途には含まれないが, エアコンが電力 消費量に及ぼす影響が大きいことを考慮して質問項目に含めている。 エネルギー消費量に関しては，1996 年1月から 1996 年 12 月までの 1 年間に㧍ける電気, ガス，水道の月別支払料金または使用量を，居 住者に記入してもらう形式とした。

調查対象の選定は，無作為抽出のような統計的手法によるサンプ
表 1 調查内容

\begin{tabular}{|c|c|}
\hline 世带属性 & 家族構成，家族構成員の年齡・職業, 対象住宅全体の税込年収 \\
\hline 住居属性 & 所在地, 形態, 構造, 新築年次, 部屋構成, 床面積 \\
\hline $\begin{array}{l}\text { 電気機器の } \\
\text { 所有状況 }\end{array}$ & 電気機器の所有台数, 冷蔵庫・テレビ・洗濯機の容量・種類 \\
\hline $\begin{array}{l}\text { エネルギー } \\
\text { 消費量 } \\
\end{array}$ & $\begin{array}{l}\text { 電気・ガス・水道月別支払料金または使用量 } \\
(1996 \text { 年 } 1 \text { 月二 1996 年 } 12 \text { 月) }\end{array}$ \\
\hline 表 2 & 機器 \\
\hline 用途 & 電気機器 \\
\hline $\begin{array}{l}\text { 調理 } \\
\text { (18 機器) }\end{array}$ & 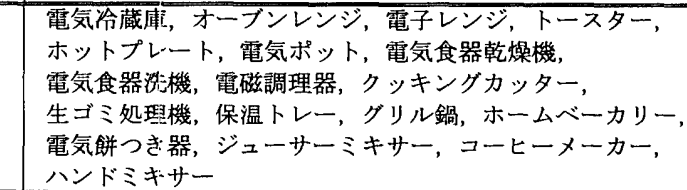 \\
\hline $\begin{array}{l}\text { 冷暖房・空調 } \\
\text { (13 機器) }\end{array}$ & $\begin{array}{l}\text { 冷暖房用エアコン, 泠房用エアコン, 扇風機, } \\
\text { 電気ファンヒーター, 電気ストーブ, 電気こたつ, } \\
\text { 足温器, 電気毛布, 電気カーペット, 除湿器, 加湿器, } \\
\text { 換気, 空:気清浄機 }\end{array}$ \\
\hline $\begin{array}{l}\text { AV - 情報 } \\
\text { (14 機器) }\end{array}$ & 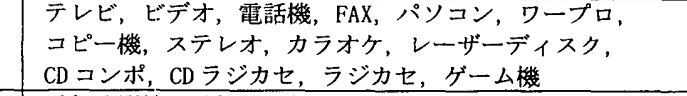 \\
\hline $\begin{array}{l}\text { 家事・衛生 } \\
\text { (12 機器) }\end{array}$ & 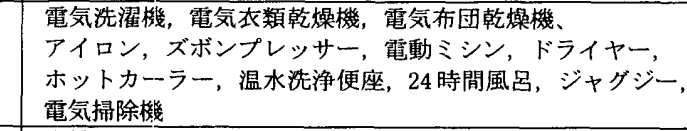 \\
\hline $\begin{array}{l}\text { その他 } \\
\text { (10機器) }\end{array}$ & 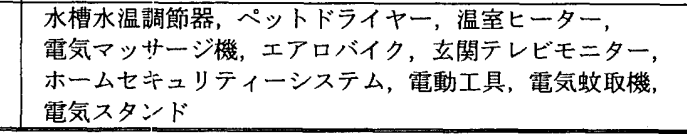 \\
\hline
\end{tabular}

表 3 調査対象地域と回収状況

\begin{tabular}{c|c|c|c|c}
\hline 対象地域 & 配布数 & 回收数 & 使用データ 件数(比率) & 電力使用量推定件数 \\
\hline 関東 & 319 & 20 & $104(44 \%)$ & 75 \\
\hline 近幾 & 260 & 209 & $92(39 \%)$ & 79 \\
\hline 東海 & 60 & 52 & $30(12 \%)$ & 17 \\
\hline 北陸 & 20 & 17 & $29(2 \%)$ & 6 \\
\hline 中国 & 20 & 16 & $4(2 \%)$ & 4 \\
\hline 東北 & 1 & 1 & $0(0 \%)$ & 0 \\
\hline 合計(回收率) & 680 & $505(74 \%)$ & 235 & 181 \\
\hline
\end{tabular}

リングではないため，本調查の対象には偏りがある。本調査は，技 術系の会社の社員を対象としており，後述のとおり，地域も関東と 近畿が中心となっている。また，全体的に年収の高い住宅の割合が 大きい。したがって，日本における標準的なサンプルであるとは言 い難いが，本報では，将涞的にどのような電気機器の普及が進み，照 明・動力他用電力消費量が増加する恐れがあるのかを把握するため の先進的なサンプルとの位置づけで調査している。

\section{3 調查対象の概要}

表 3 に示すように，回収数は 505 件であり（回収率 $74 \%$ )，対象地域 は関東と近畿が各 $40 \%$ †゙つを占めている。回答者の属性を表 4 に示 す。住宅形態は，戸建住宅と集合住宅がそれぞれ $49 \%, 51 \%$ と半数ず つを占めている。回答者の平均家族人数は 3.3 人であり, その家族構 成は，夫婦と子供から成る世帯が $60 \%$ と多く，単身者世帯も $8 \%$ 含ま れている。住居構造は，木造 $38 \%$, 非木造 $61 \%$ である。対象住宅の床 面積は, $10 〜 396 \mathrm{~m}^{2}$ の範囲にあり，平均 $97 \mathrm{~m}^{2}$ である。

\section{4 調查結果}

\section{1 電気機器の所有状況}

図 1 から図 5 に，調理用，冷暖房・空調用， $\mathrm{AV} \cdot$ 情報用，家事・衛 生用，その他の各々の用途の機器の所有率注 3 を年収別に区分して示す。 
ここで示寸結果は, 有効回答 505 件を対象としている。調査対象の機 器の所有率を，調查時期に近い1997年の統計資料に掲載されている全 国平均の普及率20) と比較する。まず，全国平均の普及率に比べて，本 調査の所有率の方が非常に高い機器について検討する。図 3 に示すと おり，ビデオは普及率 $76 \%{ }^{20}$ に対し，所有率 $97 \%$ であり，パソコンは 普及率 $22.1 \%{ }^{20}$ に対し, 所有率 $61 \%$ と非常に高い。パソコンの所有率 が高いのは，調查対象が技術関係の会社であるためであると考えられ る。図 2 に示すとおり，冷暖房用エアコンは普及率 $60 \%{ }^{20}$ に対して所 有率 $88 \%$, 図4に示すとおり，温水洗浄便座は全国平均の普及率 $24 \%$ ${ }^{200}$ に対して所有率 $48 \%$ である。これらの機器の所有率が高いのは，居 住者の衛生・快適性志向の現れであると考えられる ${ }^{20)}$ 。全般的な所有 率の高さは後述のように，調查対象が高額年収者であることを反映 していると推察される。

表 4 回答者の属性

\begin{tabular}{|c|c|c|c|c|c|c|c|}
\hline \multirow[t]{2}{*}{ 家族構成 } & \multirow[t]{2}{*}{ 件数 } & \multicolumn{2}{|c|}{ 住居形態 } & \multicolumn{3}{|c|}{ 住居構造 } & \multirow{2}{*}{$\begin{array}{c}\text { 平均床面積 } \\
\left(\mathrm{m}^{2}\right)\end{array}$} \\
\hline & & 㠍 & 建 & $\begin{array}{l}\text { 木 } \\
\text { 造 }\end{array}$ & $\begin{array}{l}\text { 非 } \\
\text { 木 } \\
\text { 浩 }\end{array}$ & $\begin{array}{l}\text { 不 } \\
\text { 明 }\end{array}$ & \\
\hline 単身者 & 42 & 41 & 1 & 4 & 37 & 1 & 35 \\
\hline 夫婦のみ & 97 & 76 & 21 & 18 & 78 & 1 & 70 \\
\hline 夫婦と子供* & & & & & & & \\
\hline 小学生以下 & 135 & 78 & 57 & 44 & 89 & 2 & 87 \\
\hline 中学生～大学 & 95 & 26 & 69 & 44 & 51 & 0 & 111 \\
\hline 社会人 & 74 & 17 & 57 & 45 & 29 & 0 & 129 \\
\hline $\begin{array}{l}\text { 親夫婦や子供 } \\
\text { 夫婦と同居 }\end{array}$ & 48 & 1 & 47 & 29 & 19 & 0 & 154 \\
\hline その他** & 12 & 5 & 7 & 7 & 5 & 0 & 82 \\
\hline 不明 & 2 & $\frac{\pi}{1}$ & 1 & 1 & 1 & 0 & 105 \\
\hline 全体 & 505 & 245 & 260 & 192 & 309 & 4 & 97 \\
\hline
\end{tabular}

“子供は長子年路を基淮とした **親子、知人との同居など

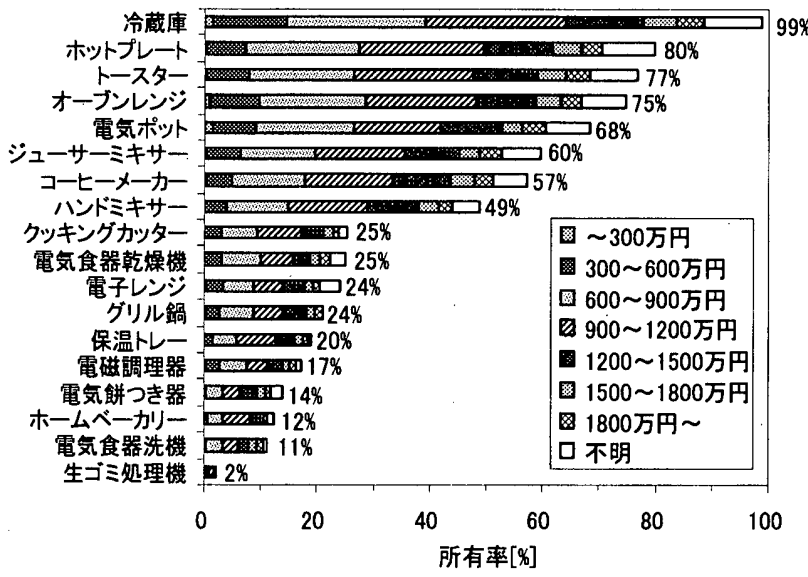

図 1 調理用機器の所有率 (\%)

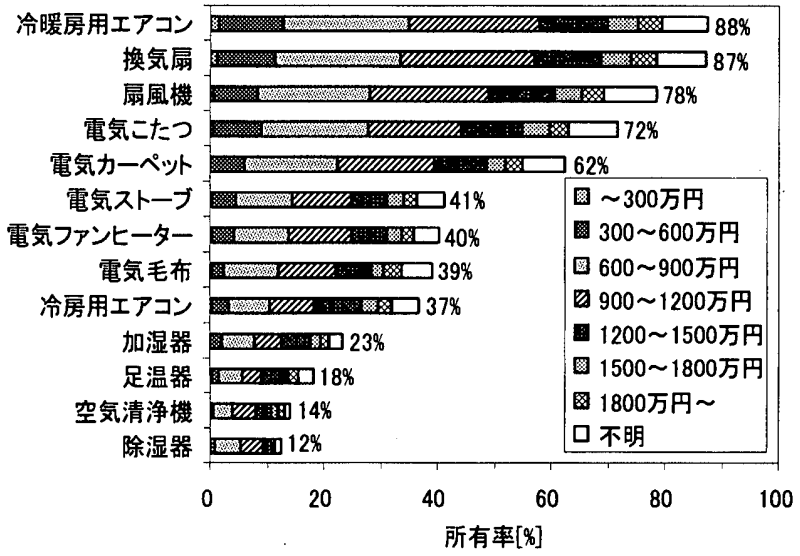

図 2 冷暖房・空調用機器の所有率 $(\%)$
次に，所有率はまだ高くないが，今後のライフスタイルによって は普及が進むと考えられる機器について検討寸る。図 1 に示すよう に, 電気食器乾燥機の所有率は $25 \%$, 図 4 に示すように, 電気布団 乾燥機，電気衣類乾燥機の所有率はそれぞれ $35 \% ， 31 \%$ である。こ れらの機器は，家事時間の短縮とともに今後普及が進む可能性があ

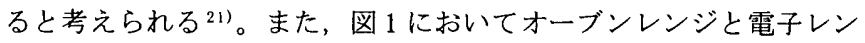
ジの所有率を，図 2 において冷暖房用エアコンと冷房用エアコンの 所有率を比較するとわかるように，多機能な機器の所有率が高い。

なお，機器の所有台数については，テレビと冷暖房用エアコンで複 数所有が顕著であり，全所有世帯のうち2台以上所有している割合は, テレビ $67 \%$ ，冷暖房用エアコン $58 \%$ である。

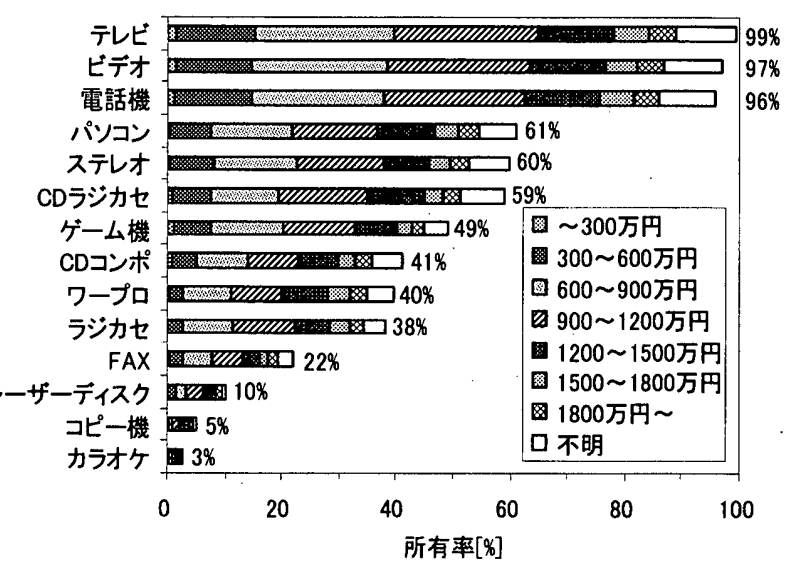

図 $3 \mathrm{AV} \cdot$ 情報用機器の所有率 $(\%)$

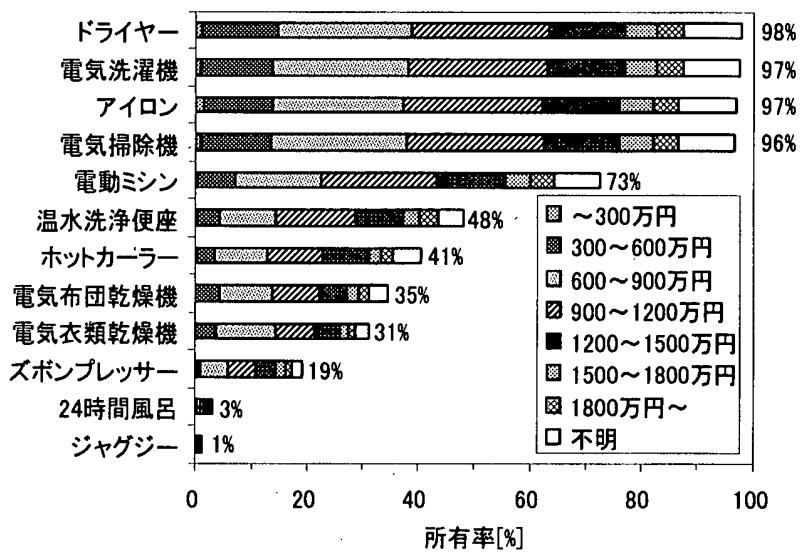

図 4 家事・衛生用機器の所有率 $(\%)$

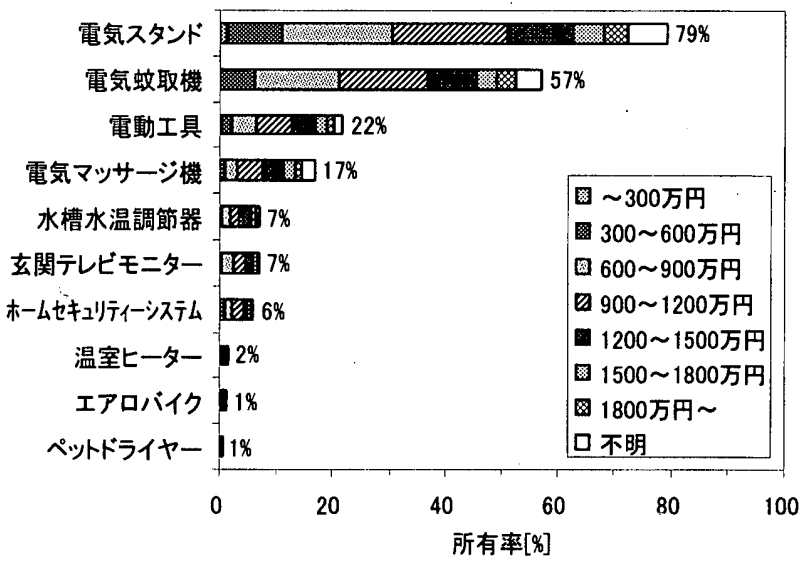

図 5 その他の機器の所有率 (\%) 
その他の電気機器では多様化が顕著であり，表 2 のアンケートに提 示した 10 機器以外に 65 機器の回答が得られた。65機器を更に用途別 に分類すると, 美容・健康用, 楽器類, ペット用, 水槽用, ホームセ キュリティー関連, 照明, 充電器, ポンプ類, 医療用, チューナー・ コンバーター類，その他と分類される。その他には，熱源が電気以外 の機器であり，例えば石油ファンヒーター等のように，時間表示や予 約設定のためにコンセントにつないでおり，微量の電力消費がある機 器が含まれる。

\section{2 機器の大きさ(容盟) と種類}

所有機器の大きさの実態を把握するために, 主要な電気機器である

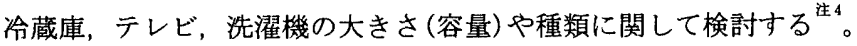
有効回答 505 件の冷蔵庫の容量, テレビの大きさ，洗濯機の容量につ いて，それぞれ図6，図7，図8に示す。図6に示すとおり，冷蔵庫の 容量は $300 \mathrm{~L}$ 以上 $400 \mathrm{~L}$ 未満が最も多く, 次いで多いのは $400 \mathrm{~L}$ 以上 $500 \mathrm{~L}$ 未満である。冷蔵庫の容量は, $300 \mathrm{~L}$ 以上が所有世帯全体の $75 \%$ を占め ている。図7に示すとおり，所有しているテレビのうちで最も大きい テレビの大きさは 25 インチ以上 29 インチ以下が最も多く，25インチ 以上が所有世帯全体の $64 \%$ を占めている。図8に示すとおり，洗濯機 の容量は, $4 \mathrm{~kg}$ 以上 $5 \mathrm{~kg}$ 末満, $5 \mathrm{~kg}$ 以上 $6 \mathrm{~kg}$ 末満が多く, 容量 $5 \mathrm{~kg}$ 以上 が所有世帯全体の $59 \%$ を占めている。いずれの機器においても，より 大型の機器を所有する傾向が見られる。なお，図示していないが，洗 濯機の種類の内訳は，全自動 $84 \%$ ，二槽式 $16 \%$ である。

\section{3 使用時以外における電力消費に対する認識度}

アンケート調查において，機器の所有台数を問う質問と共に，「使 用時以外にも電力を消費する可能性があるかどうか」という質問を設 け,この項目をチェックしていた世帯の所有世帯全体に対する割合を 有効回答 505 件を対象として算出した。図 9 に，認識度が $20 \%$ 以上の 機器について示す。待機電力に対する認識度は, テレビやビデオをは じめ, FAX, 電話機, $\mathrm{CD}$ コンポ，ステレオ等の $\mathrm{AV} ・$ 情報用で $48 \%$ 78 \%であり, AV・情報用電気機器の待機電力に関しては比較的認識され ているという結果を得た。一方，AV・情報用以外の用途に関しては， オーブンレンジ $59 \%$, 温水洗浄便座 $56 \%$ の認識度があるのを除いて, 電子レンジ $25 \%$, 電気ポット $23 \%$, 冷暖房用エアコン $43 \%$ の認識度 にとどまっている。リモコンが付属している機器はAV・情報用に多 く，主電源を付けたままにしているために待機電力が生じることは比 較的認識されているのではないかと考えられる。しかし，長時間の通 電により無駄な電力を消費する機器が多いことや, プラグを差し込ん だだけの状態でも電力を消費する機器があることに関しては認識度が 低いものと推察される。今後は居住者の待機電力に対する認識を高め ていくことが重要であろう。

\section{4 年間電力消費量}

回収した 505 件のサンプルのうち，住宅全体の年間電力消費量が把 握できた 238 件に関する結果を以下に示す ${ }^{\text {注 }}$ 。2 238 件の住宅の床面積 は17〜396 $\mathrm{m}^{2}$ の範囲にあり, 平均 $101 \mathrm{~m}^{2}$ である。家族人数は $1 \sim 6$ 人の 籁囲にあり，平均 3.5 人である。なお，本報ではエネルギー消費量の 結果は、電力のみを対象としているので、単位は原則としてMWh で示 し，必要に応じて括弧書きで電気の熱量換算値も示す ${ }^{\text {注 } 6}$

\section{(1) 年間電力消費量の分布と他調亘との比較}

図 10 に, 年間電力消費量の度数分布を示寸。年間電力消費量の平均 は5MWh/a (17GJ/a)であるが, 1〜20MWh/a (3〜 72GJ/a) の広い範囲にあ

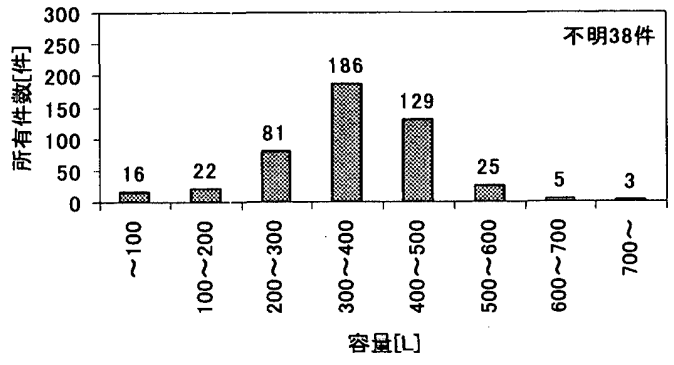

図 6 冷蔵庫の容量別所有件数

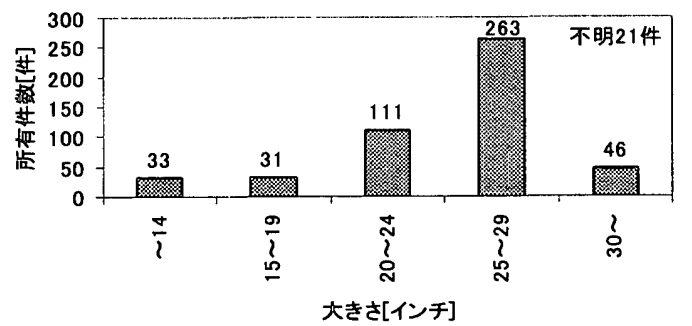

図 7 デレビの大きさ別所有件数

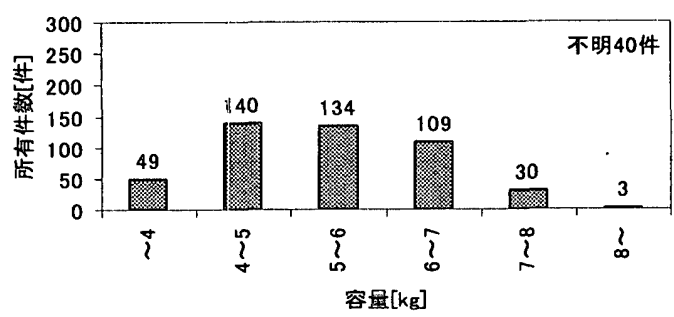

図 8 洗濯機の容量別所有件数

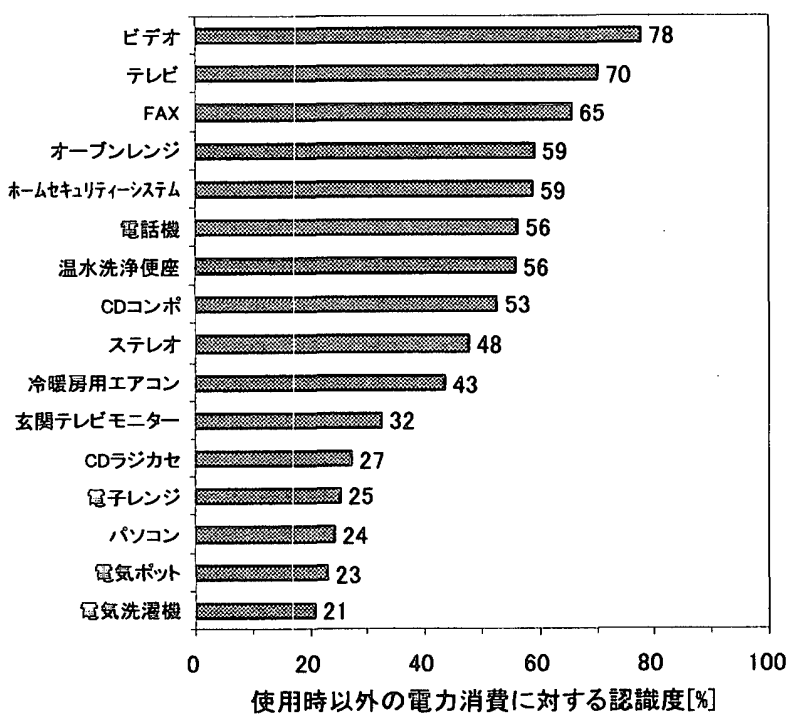

図 9 「使用時以外にも電力を消費する可能性があるかどうか」に 対ずる居住者の認識度 (\%)

る。年間電力消費量 $3 M W h / a$ 以下のサンプル中には単身世帯が含ま れており，年間電力消費量 $12 \mathrm{MWh} / \mathrm{a}$ 以上のサンブル中には電気温水 器等の樑夜電力利用住宅や，セントラル暖房を行っている住宅が含 まれている。電力消費量の分布の広さは，ライフスタイルやエネル ギーの使い方の違いが個々の住宅によって大きいことを反映してい

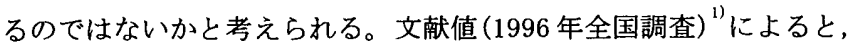
年間電力消費量は $16 \mathrm{GJ} / \mathrm{a}$ であり, 本調査対象は文献值よりやや多 い消費量である。単位床面積当たりの年間電力消費量の平均は $51 \mathrm{kWh} / \mathrm{m}^{2} \mathrm{a}\left(182 \mathrm{MJ} / \mathrm{m}^{2} \mathrm{a}\right)$ で, $11 \sim 166 \mathrm{kWh} / \mathrm{m}^{2} \mathrm{a}\left(38 \sim 599 \mathrm{MJ} / \mathrm{m}^{2} \mathrm{a}\right)$ の範 囲にばらついている。 


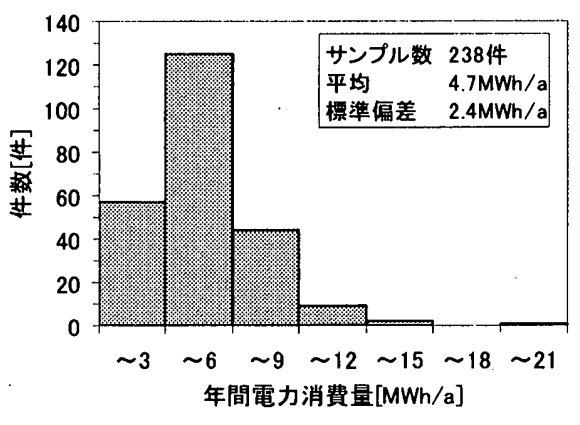

図 10 年間電力消費量の度数分布

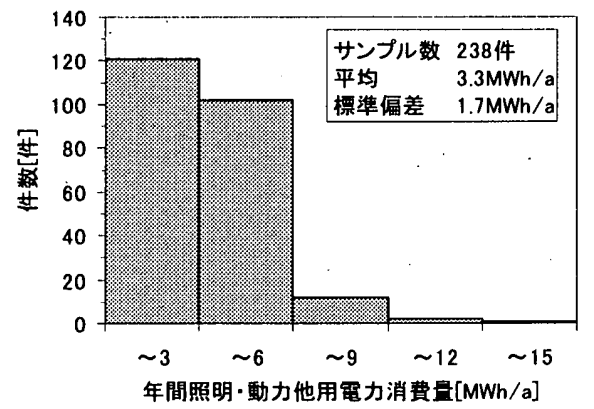

図 11 年間照明 - 動力他用電力消費量の度数分布

（2）年間照明・動力他用電力消費量の分布と他調查との比較

図 11 に，差引法 ${ }^{\text {淁7.18 }}$ により算出した年間照明・動力他用電力消費 量 ${ }^{\text {音 }}$ の度数分布を示す。年間照明・動力他用電力消費量の平均は $3 \mathrm{MWh} /$ $\mathrm{a}(12 \mathrm{GJ} / \mathrm{a})$ であり, $1 \sim 12 \mathrm{WWh} / \mathrm{a}(2 \sim 44 \mathrm{GJ} / \mathrm{a})$ の広い範囲にばらついて いる。文献值 $(1996 \text { 年全国調查) })^{1)}$ によると，年間照明・動力他用電力 消費量は $16 \mathrm{GJ} / \mathrm{a}$ であり，差引法によって算出された本調查対象の消費 量は文献値よりもやや少ない。本調查において，照明・動力他用電力 消費量が年間電力消費量に占める割合は $71 \%$ となっており，高い比率 を占めていると言えよう。単位床面積当たりの年間照明・動力他用電 力消費量の平均は $35 \mathrm{kWh} / \mathrm{m}^{2} \mathrm{a}\left(126 \mathrm{MJ} / \mathrm{m}^{2} \mathrm{a}\right)$ で, $7 \sim 98 \mathrm{kWh} / \mathrm{m}^{2} \mathrm{a}(25 \sim 352 \mathrm{MJ} /$ $\left.\mathrm{m}^{2} \mathrm{a}\right)$ の範囲にある。

\section{5 電力消費量に及ぼす因子に関する検討}

\section{1 年収と電力支払料金の関係}

住宅のエネルギー消費量のうち，照明・動力他用エネルギー消費量 は，他の用途のエネルギー消費量に比べて，年収との関係が強い傾向 があると言われている ${ }^{14)}$ 。そこで，電力支払料金が明らかな 388 件を 対象として年収と電力支払料金との関係について検討した。図12に示 すように，年収が高くなるにつれて電力支払料金も多くなる傾向が見 られ，年収と電力支払料金は正比例の関保にある。年間電気支払料金 は 2 万円から 53 万円の範囲にあり，平均 12 万円である。なお，電力 支払料金は年収の数\%に相当している。

\section{2 年間照明 ·動力他用電力消費量の重回龽分析}

照明・動力他用電力消費量は, 収入ランクと修正家族人数との相関 性があることが既往の研究で示唆されている ${ }^{14)}$ 。そこで，既往の研究 で相関が高いと言われているこれらの因子を説明変数として重回帰 分析を行った。対象は, 年間電力消費量や電気機器の所有台数の回 答に欠落のない住宅 238 件である。重回帰分析を行った結果，式(1) を得た。説明変数は，家族人数 ${ }^{\text {草 }}$, 年収ランク ${ }^{\text {注 } 10}$, 電気機器の総所 有数 ${ }^{211}$ である。また，年収と電気機器の総所有数の関係は図 13 の とおりであるが，これら 2 つの説明変数は統計的に独立であること

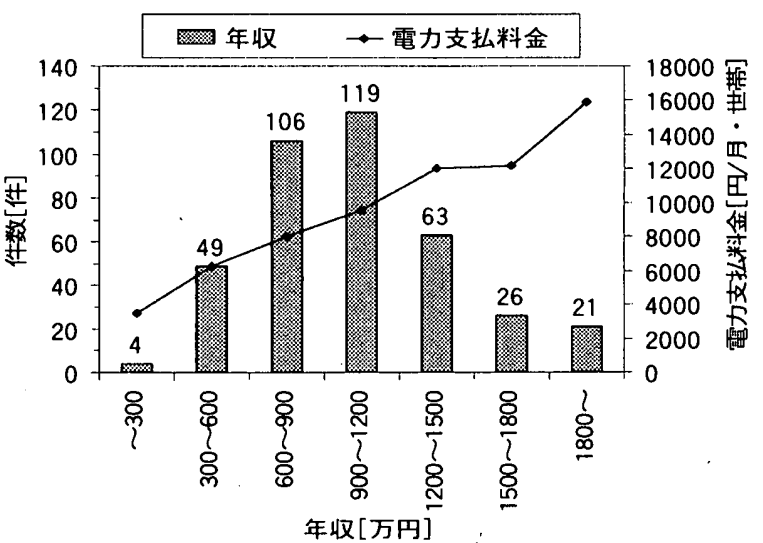

図 12 年収と月別電力支払料金との関係

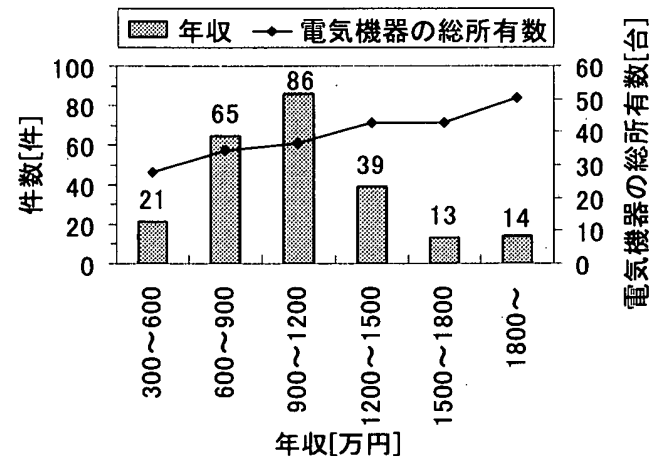

図 13 年収と電気機器の総所有数の関係

を確認している ${ }^{\text {住 } 12}$ 。

$\mathrm{y}=0.23 * \mathrm{x}_{1}+0.35 * \mathrm{x}_{2}+0.062 * \mathrm{x}_{3}-0.86$

（重相関係数 0.71 , 奇与率 0.50 )

$\mathrm{y}$ :年間照明 - 動力他用電力消費量 $[M W h / a]$

$\mathrm{x}_{1}$ : 家族人数 $[人], \mathrm{x}_{2}$ : 年収ランク $[-], \mathrm{x}_{3}$ : 電気機器の総所有数 $[$ 台 $]$ 本調查対象の $50 \%$ の年間照明・動力他用電力消費量は式(1)で説明 することができ，標準偏回帰係数は，家族人数 0.15 , 年収ランク 0.26 , 電気機器の総所有数 0.47 である。年間照明・動力他用電力消費量は, 式(1)から，家族人数が 1 人増加すると $230 \mathrm{kWh}$ ，年収ランクが 1 ランク 高くなると $350 \mathrm{kWh}$, 電気機器を現状よりも 1 台多く所有すると $62 \mathrm{kWh}$ 増加することが予測できる。238 件の一月当たりの平均照明・動力他 用電力消費量は $278 \mathrm{kWh}$ であるが, これは電気機器の総所有数が現状よ りも 4.5 台增加した場合に相当する。今後の新しいライフスタイルに よって，住宅における電気機器の所有台数の増加が予想でき，それに 伴う照明・動力他用電力消費量の増加が䁅念される。各機器の使用頻 度を考慮する必要はあるが, 年収と電気機器の総所有数で照明・動力 他用電力消費量の大体の傾向は掴むことができると言えよう。

\section{3 照明・動力他用電力消費量の数量化分析}

前述の重回帰分析では, 電気機器の総所有数を説明変数の一つに用 いたが，実際にどのような電気機器が照明・動力他用電力消費量に影 響を及ぼすのかについては不明である。そこで, アンケートで調査し た機器の所有状況を基に, 年間照明・動力他用電力消費量に及ぼす因 子に関する検討を行った。対象としたのは，前述の重回帰分析で用い たサンプルと同様, 年間電力消費量や電気機器の所有台数の回答に 久落がない 238 件である。目的変数を年間照明・動力他用電力消費 量, 説明変数を年間照明・電力他用電力消費量と関連があると思わ れる 36 因子を選択し9), 13)，14)，数量化理論 I 類による分析を行った。 
表 5 年間照明 - 動力他用電力消費量の数量化 I 類による分析結果

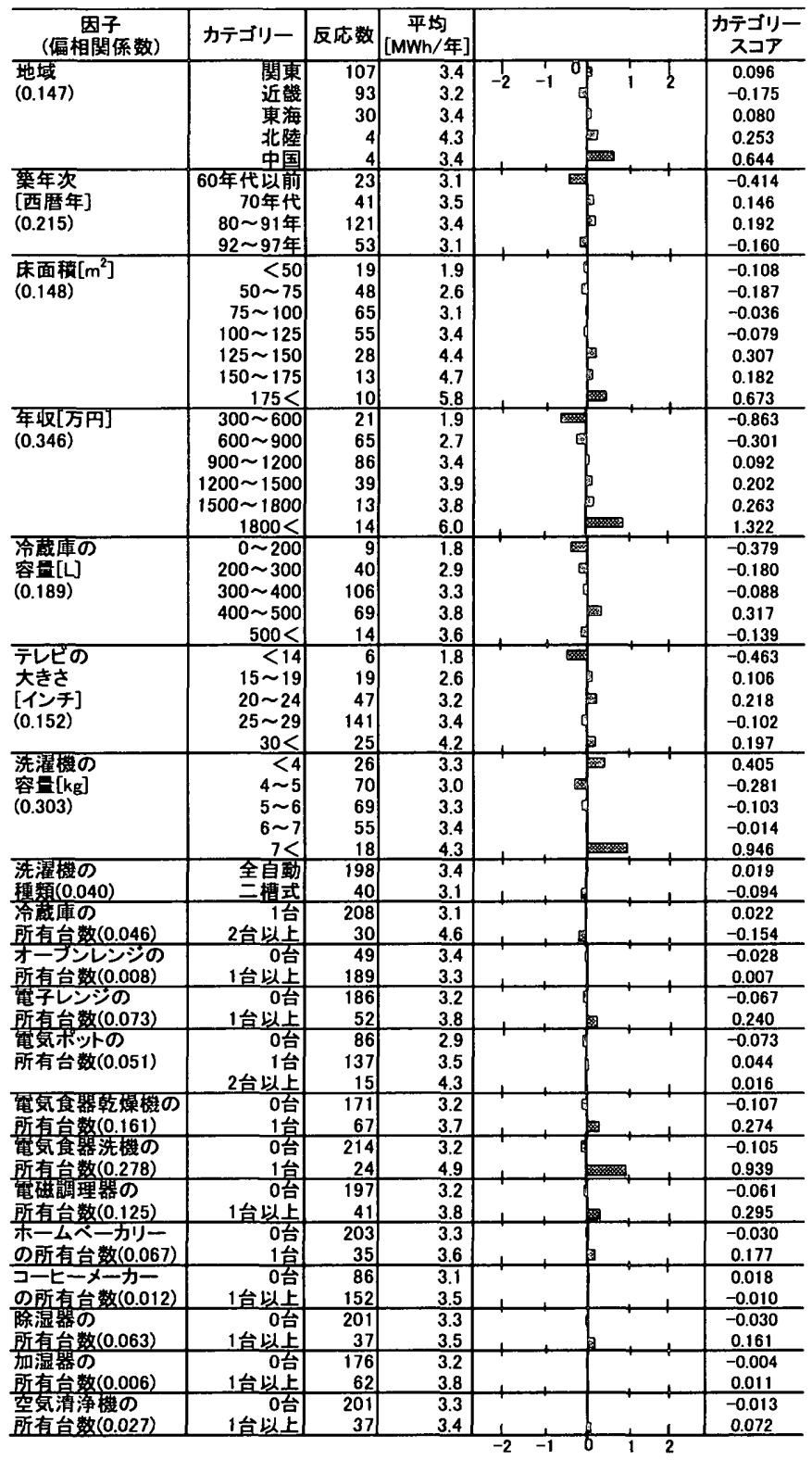

世帯属性に関する因子として，地域，築年次，床面積，年収を，電 気機器の所有状況に関する因子として, 各電気機器の所有台数の他, 冷蔵庫やテレビ，洗濯機の容量を選択している。なお，因子間に多 重共線性がないことを考慮している。

分析結果を表 5 に示す。重相関係数は 0.81 ，寄与率は 0.66 であ る。偏相関係数の最も大きい因子は年収であり，年収が 1800 万円以 上となると年間照明・動力他用電力消費量への影響力が特に大きく なっている。年収が高くなるにつれて，より多くの電気機器を所有 するようになり，エネルギー多消費につながっているものと推察さ れる。年収に次いで偏相関係数の大きい因子として, 温水洗浄便座 の所有台数, 洗濯機の容量が挙げられる。温水洗浄便座の所有台数 は 2 台以上, 洗濯機の容量は $7 \mathrm{~kg}$ 以上の場合に年間照明・動力他用 電力消費量への影響力が強くなる。洗濯機の容量は $4 \mathrm{~kg}$ 以下の場合 を除き，消費量は容量の大きさに比例して多くなっている。容量 $4 \mathrm{~kg}$ 未満の洗濯機の年間照明・動力他用電力消費量は容量 $5 \sim 6 \mathrm{~kg}$ の洗 濯機のそれと同程度である。また，500L 以上の泠蔵庫と $400 \sim 500 \mathrm{~L}$ の冷蔵庫の消費量も同程度である。回答者の所有機器が旧型であっ

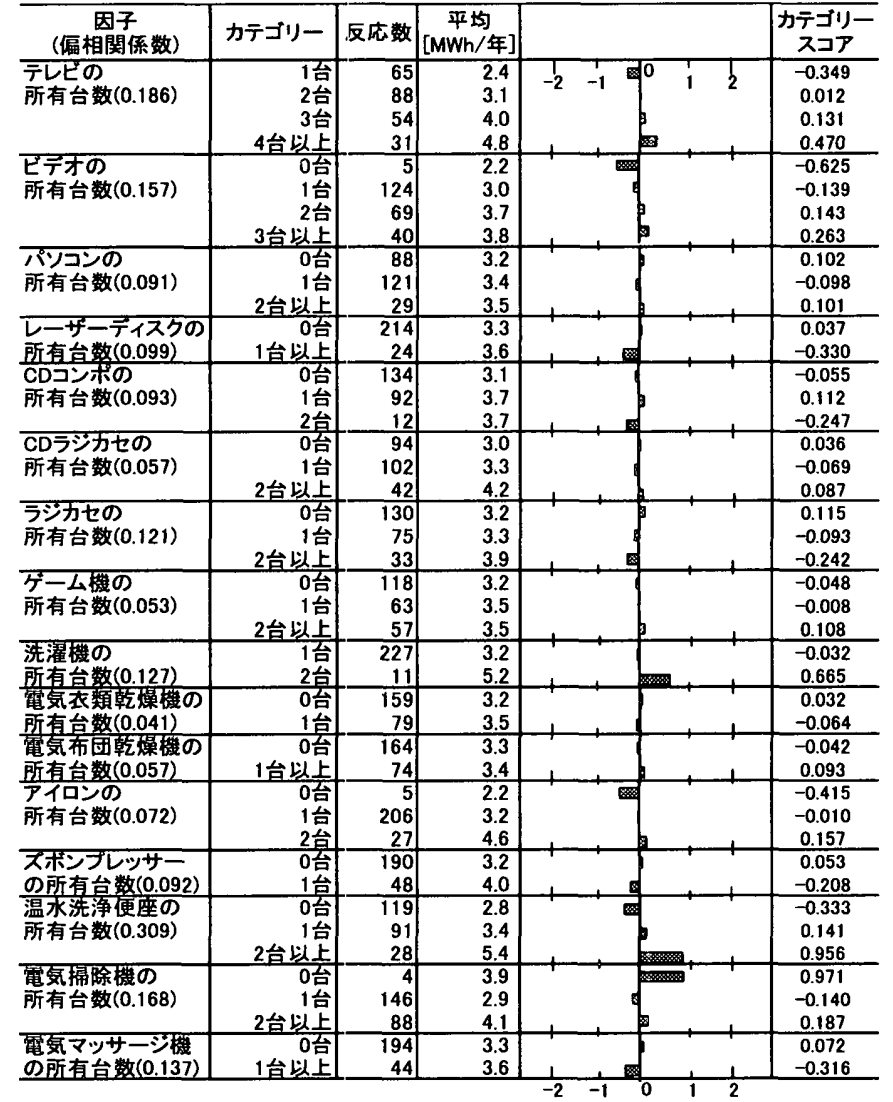

たために消費電力量の削減が進んでいないのか, 製品として主流の 容量以外ではメーカーによる消費電力量削减が進んでいないのかは 定かではないが，どのような容量でも消費電力量の削減は必要であ ろう。前述の因子以外で偏相関係数の大きい因子として, 電気食器 洗機の所有台数や住宅の築年次, 冷蔵庫の容量が挙げられる。逆に, 偏相関係数が小さい因子として, 加湿器, オーブンレンジ, コーヒー メーカー, 空気清浄機, 衣類乾燥機の所有台数や洗濯機の種類が挙 げられる。ただし, 本論文では機器の使用頻度を考慮していないた め, 個々の住宅において各電気機器の使用頻度を考慮に入れること が，電力のピーク負荷や筑負荷を検討する上で重要であろう。冷蔵 庫, テレビ, 洗濯機については所有台数と容量の両者を因子として 選択しているが, 冷蔵庫と洗濯機は容量, テレビは所有台数の影響 力が強いと判断される。年間照明・動力他用電力消費量を地域別に 比較すると，北陸を除け济同程度の消費量となっている。床面積が 大きくなるほど，年間照明・動力他用電力消費量は增加する傾向に あるが，これは床面積が大きくなるのに伴って，所有する電気機器 の台数も増加するためである。ただし，地域と床面䄼の偏相関係数 は $0.147,0.148$ と小さい。

\section{6 住宅における電気機器所有の類型化}

前章の数量化分析においては，世帯属性因子や電気機器の所有に 関わる因子が年間照明・動力他用電力消費量に及ぼす影響度に関し て検討を行った。本章で汹電気機器の所有状況に基づいて, 調查対 象世帯の類型化を行うことによって，照明・動力他用電力消費量を 整理することを目的として，Ward 法を用いたクラスター分析を行っ た。対象としたのは, アンケートの回答に欠落がない 238 件のうち, 
戸建住宅に住む 4 人家族 66 件である。分析対象としたデータは, 数 量化分析にて偏相関係数の高かった年収, 冷蔵庫・洗濯機の容量, 電 気食器洗機・テレビ・温水洗浄便座の所有台数の 6 項目である。ク ラスター数は, 図示はしていないが, 得られた樹形図の形状から距 離 10 で切断し, 表 6 に示すとおり A，B，C，Dの4つのグループに 分類した。類型化した各グループの属性を表 7 に示す ${ }^{\text {13 }}$ 。表 7 から, テレビの所有台数の大小が $\mathrm{A}, \mathrm{B}, \mathrm{C}, \mathrm{D}$ の 4 つのグループに対忘して いることがわかる。また，年収によってもある程度の類型化が可能 であると考えられる。年収は比較的多いが電気機器の総所有数は少 ないグループA と, 年収は少ないが電気機器の総所有数はグループ A よりもやや多いグループ B を比較すると, 冷蔵庫や洗濯機の容量は 雨グループとも同程度であることがわかる。一方, グループ C とグ ループD はいずれも年収が多く, 電気機器の総所有数も多いが, グ ループD は所有機器の容量はグループ C に比べて小さいにもかかわ らず，単位床面積当たりの照明・動力他用電力消費量はグループ C よりも多い。グループD は機器の買い替えをせずに古い機器を使い 続けており, 待機電力が削減されていない機器を使用していること

表 6 戸建住宅 4 人家族 66 件を対象とした類型化の結果

\begin{tabular}{|c|c|}
\hline 類型 & 特徴 \\
\hline $\begin{array}{l}\text { グループA } \\
(\mathrm{N}=23)\end{array}$ & $\begin{array}{l}\text { 年収が比較的多いが,電気機器の大きさや総所有数はグループBと } \\
\text { 同程度である。床面積当たりの消費量はグループBよりも多い。 }\end{array}$ \\
\hline $\begin{array}{l}\text { グループB } \\
(\mathrm{N}=16)\end{array}$ & $\begin{array}{l}\text { 年収は4グループ中最も少ないが, 電気機器の大きさや総所有数は } \\
\text { グループA と同程度である。床面積当たりの消費量は } 4 \text { グループ } \\
\text { 中最も少ない。 }\end{array}$ \\
\hline $\begin{array}{l}\text { グループC } \\
(\mathrm{N}=14)\end{array}$ & $\begin{array}{l}\text { 年収が多く, 大型機器を所有し, 電気機器の所有台数が多いが, } \\
\text { 床面積当たりの消費量はグループCに比べて小さい。 }\end{array}$ \\
\hline $\begin{array}{l}\text { グループD } \\
(\mathrm{N}=13)\end{array}$ & $\begin{array}{l}\text { 非常に年収が多く, 電気機器の所有台数が多いが, 大型機器は } \\
\text { グループCに比べて少ない。床面積当たりの消費量は } 4 \text { グループ } \\
\text { 中最も大きい。 }\end{array}$ \\
\hline
\end{tabular}

表 7 戸建住宅 4 人家族 66 件の類型化別属性

\begin{tabular}{|c|c|c|c|c|c|}
\hline \multicolumn{2}{|c|}{ 項目 } & A & $\mathrm{B}$ & $\mathrm{C}$ & D \\
\hline \multicolumn{2}{|c|}{ 平均床面積 $\left(\mathrm{m}^{2}\right)$} & 114 & 111 & 138 & 125 \\
\hline \multicolumn{2}{|l|}{ 平均年収 (万円) } & 1154 & 750 & 1307 & 1396 \\
\hline \multicolumn{2}{|l|}{ 世帯主年齢 (歳) } & 45 & 40 & 49 & 53 \\
\hline \multicolumn{2}{|l|}{ 長子年齢 (歳) } & 16 & 11 & 19 & 23 \\
\hline \multicolumn{2}{|c|}{ 電気機器総所有数 (台) } & 37 & 40 & 48 & 51 \\
\hline \multicolumn{2}{|c|}{$\begin{array}{l}\text { 最も大きいテレビの大きさ } \\
\text { (インチ) }\end{array}$} & 26.1 & 25.0 & 27.4 & 29.3 \\
\hline \multicolumn{2}{|c|}{ 冷蔵庫の容量 $(\mathrm{L})$} & $300 \sim 400$ & $300 \sim 400$ & $400 \sim 500$ & $300 \sim 400$ \\
\hline \multicolumn{2}{|c|}{ 洗濯機の容量 $(\mathrm{kg})$} & $5 \sim 6$ & $5 \sim 6$ & $6 \sim 7$ & $4 \sim 5$ \\
\hline \multicolumn{2}{|c|}{ テレビの所有台数 (台) } & 1.7 & 2.3 & 3.2 & 4.1 \\
\hline \multicolumn{2}{|c|}{ パソコンの所有台数(台) } & 0.8 & 0.6 & 0.9 & 0.7 \\
\hline \multicolumn{2}{|c|}{ 電気食器洗機の所有台数 (台) } & 0.2 & 0.1 & 0.1 & 0.2 \\
\hline \multicolumn{2}{|c|}{ 温水洗浄便座の所有台数 (台) } & 0.6 & 0.6 & 0.9 & 0.8 \\
\hline \multirow{2}{*}{$\begin{array}{l}\text { 照明・動力他用 } \\
\text { 電力消費量 }\end{array}$} & (MWh/年) & 3.5 & 2.9 & 5.0 & 4.6 \\
\hline & (kWh/m² 年) & 31 & 26 & 36 & 37 \\
\hline
\end{tabular}

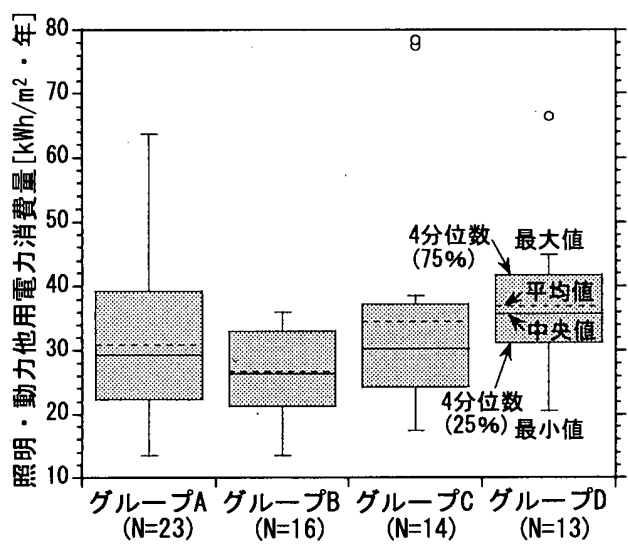

図 14 類型別照明 - 動力他用電力消費量
が原因となって消費量が多いのではないかと推測される。グループ $\mathrm{A}$ とグループC を比較すると, 後者の方が冷蔵庫と洗濯機の容量が大 きい。このことから，世帯主年齢が $45 \sim 49$ 歳，長子年齢が $16 〜 19$ 歳の間に大型の機器に買い替える時期があるのではないかと推測さ れる。類型化別照明・動力他用エネルギー消費量の分布を図 14 に示 す ${ }^{i 4}$ 。グループA を除けばばらつきは小さい。グループDのように, 単位床面積当たりの照明・動力他用電力消費量が最も大きいグルー プに関しては，エネルギーの使い方に対する意識を高める必要があ ると思われる。

\section{7 まとめ}

関東・近畿地方を中心とする住宅 505 件を対象として, 電気機器 の所有状況とエネルギー消費量に関するアンケート調查を行い，照 明・動力他用電力消費量について分析・考察を行った。その結果，以 下の知見が得られた。

（1）電気機器の所有率を算出したところ，その所有状況には家事時間 の短縮や衛生・快適性志向のライフスタイルが反映されているこ とがわかった。電気機器の所有状況を把握することはライフスタ イルの変化を捉える上で重要であると考えられる。現在普及率が 低くても，新しいライフスタイルとともに今後普及が進み，電力 消費量の増加につながる可能性があることを考慮する必要がある。

（2）住宅における電気機器のうち，給湯以外の用途に該当する機器を 調理, AV ・ 情報, 冷暖房・空調, 家事・衛生, その他と分類した 場合のその他に当たる機器を美容・健康用, 楽器類, ペット用, 水 槽用，ホームセキュリティー関連，照明，充電器，ポンプ類，医 療用，チューナー・コンバーター類，その他と体系的に分類した。

(3) 住宅で所有される電気機器は多様化しており, 所有の特徵として, 機器の多機能化や大型化, 複数所有の傾向が強い。

(4) 使用時以外における電力消費量に対する認識度には機器の用途に よる違いが見られ，例えばテレビ等の AV・情報用機器では比較的 認識されているが，それ以外の用途では認識度が低いことがわ かった。使用時以外の電力消費量削减は非常に重要な課題であり, 居住者の認識を高めるために，情報を周知していく必要がある。

（5）年間電力消費量は $1 \sim 20 \mathrm{MWh} / \mathrm{a}$ の広い範囲にあり, 平均 $5 \mathrm{MWh} / \mathrm{a}$ で ある。年間照明・動力他用電力消費量は $1 \sim 12 \mathrm{MWh} / \mathrm{a}$ の範囲にあ り, 平均 $3 M W h / a$ である。

（6）年間照明・動力他用電力消費量に影響を与える因子を検討するた めに, 世帯属性や電気機器の所有台数, 機器の容量を因子とし て，数量化 I 類による分析を行った。その結果，年収，温水洗 浄便座の所有台数, 洗濯機の容量の影㗽力が強いことがわかっ た。その他, 電気食器洗機の所有台数や住宅の築年次, 冷蔵庫 の容量の影響力も強い。年間照明・動力他用電力消費量に及ぼ す影響力が強い機器に関して，容量の大小にかかわらず，更な る消費電力削減を進める必要がある。

（7）戸建住宅に住む 4 人家族 66 件を対象に，年収および幾つかの電 気機器の所有状況を基にしてクラスター分析を行ったところ，4 つのグループに類型化することができた。照明・動力他用電力 消費量の多いグループに関しては，エネルギーの使い方に対す る意識を高めていく必要がある。 


\section{あとがき}

本研究は, 1996年に生活価值創造住宅開発技術研究組合自主研究会 (主査 栗原 潤一)及び第5分科会(主查 吉田尚弘)において行われた研究成果の一部である。 アンケート調查に御協力頂いた関倸各位にここに記して感謝の意を表する。

注

1）本報は既発表論文 27)に加筆・修正を加えたものである。

2） 21 世紀に向けて生活の新しい価值を創造できる良質な住宅を供給する目的 で归通商産業省により1994年11月に発足した技術研究組合。

3）所有率は, 機器を 1 台以上所有している世带数が回收した全サンプル505件 に占める割合として算出している。全国統計調查の普及率に相当するが, 本 報では敢えてこれと区別している。なお，「電話機」と「FAX」の区別に関し ては, FAX 付電話機については「FAX」にカウントし, FAX機能が付いていな い電話機に関しては「電話機」にカウントした。

4）機器を複数所有している場合，冷蔵庫，洗濯機に関しては最も大きい機器の 容量を,テレビに関しては個々の機器の大きさを記入してもらった。

5）年間電力消費量が明らかな 238 件のうち183件に関しては, 電力料金から電 力使用量を逆算した值を用いている。

6）電気の熱量換算には，二次エネルギー換算値 $3.6 \mathrm{MJ} / \mathrm{kWh}$ を用いている。

7）エネルギー消費量を用途別に推定する方法として，差引法と積算法がある。 例えば, 電気消費量を用途別に推定する場合, 差引法は, 各月の電気消費量 から，消費量が最も少ない月の数量を差引き，残量を冷暖房と寸る方法であ り, 積算法は, 器具の容量, 使用時間, 使用日数, 所有台数を調查して, 女 献 18 幾つかの数式を用い, 用途ごとに器具による電気消費量を積算して 用途別電気消費量を推定する方法である。

8） 12 ヶ月中, 月別電力消費量の最も少ない月の電力消費量を 12 倍したものを 年閒の照明・動力他用電力消費量と考えて試算した。

9) 文献 14 では, 10 才末満の子供を 0.5 人と勘定して得られる家族人数を 修正家族人数と定義して用いていたが本調查では算出が難しいため, 本来の家族人数をそのまま説明変数として用いている。

10）文献 14 とは収入の階級幅が異なっている。本調查では，税込みの家族 の年間収入を次の 6 つのランクに分類した。すなわち，300 万円以上 600 万円未満 (ランク 1)，600 万円以上 900 万円未満 (ランク 2)，900 万 円以上 1200 万円未満 (ランク 3)，1200 万円以上 1500 万円未満(ランク 4)，1500 万円以上 1800 万円末満 (ランク 5)，1800 万円以上(ランク 6) である。

11）アンケートに記入のあった冷暖房機器以外の電気機器の所有台数の合計值で ある。個々の機器の使用頻度に関する質問は設けておらず, 使用頻度は考慮 されていないので所有しているだけで使用頻度が低い機器も含まれている。

12）有意水準 $5 \%$ にて有意であることを確認している。

13）表7において, 冾蔵庫と洗濯機の容量に関しては最頻値を示し，それ以外の 項目についてはグループ別の平均値を示している。

14）図14において, 各ボックスは変数の $50 \%$ を囲み, 変数の中央值はラインて 表示される。また，ボックスの上下ラインは変数母集団の $\pm 25 \%$ の限界を 表す。各ボックスの上下間のラインは許容範囲内にある最大值と最小值を示 している。この範囲外にある值は外九值と呼ばれ，個々の点で表示される。 中央值と最大值の中間に位置するデータの值を上4分位数 (UH), 中央值と最 小值の中間に位置するデータの值を下 4 分位数 (LH) とし，その差を4分位数 間距離 $(\mathrm{HS})$ とすると，外れ值は，UH+1. $5 \times$ HS または LH-1. $5 \times$ HS となる。

\section{参考文献}

1）住環境計画研究所編：家庭用エネルギーハンドブック，財団法人省エネル ギーセンター, 1999. 3.

2）財団法人 住宅・建築 省エネルギー機樥 : 住宅の次世代省エネルギー基淮 と指針, 1999.11.

3) Hidetoshi NAKAGAMI, Akio TANAKA, Chiharu MURAKOSHI and Osamu ISHIHARA: CHANGES IN RESIDENTIAL ENERGY CONSUMPTION PATTERNS AND FUTURE TREND IN JAPAN 我が国の家庭用エネルギー消費構造の変遷と将来予測, 日本建築 学会計画系論文集, 第 555 号, pp. 53-60，2002.5.

4）福島逸成，浦野良美，渡辺俊行 : 九州地域における住宅エネルギー消費構造 に関する研究，空気調和・衛生工学会論文集, No. 57, pp. 35-48, 1995年2月.

5）洪元和:集合住宅における住戸属性と年間エネルキー消費の分析，日本建築学 会計画系論文集，第 445 号, pp. 53-61，1993.3.

6）田中昭雄，酒井孝司，中上英俊，村越千春，石原修:住宅種別用途別エネルギー 消費量推定に関する研究，日本建筑学会計画系論文集，第539号, pp. 67-74, 2001.1 .
7）商品科学研究所：エネル:キー消費とライフスタイル，CORE，第19巻第4号, pp. $43-44,1992.10$

8）長野克則，中村真人，落藤澄，渡辺英紀，永坂茂之：札幌における家庭用エネ ルギ消費星の実態調查 第2報 エネルギ消費量にかかかる諸要因の検討, 架 気調和・街生工学会学術講演会講演論文集, pp. 265-268，1993. 10.

9）椛田考一:世帯構成を考慮した戸建住宅の用途別エネルギー消費量の推定，日 本建築学会大会学術講演梗概集環境工学 II , pp. 73-74, 1997.9.

10) 尾島俊雄, 增田康広: 住宅におけるエネルギ消費実態調査 第3報 エネルギ 消費実態に関する全国調㿽 (1) 統計資料の解析と質問紙調查の概要, 空気調和・ 衛生工学会論文集, No. 12, pp. 53-65, 1980. 2.

11）尾島俊雄, 增田康広: 住宅におけるエネルギ消費実態調查 第 4 報 エネルギ 消費実態に関する全国調查 (2) 冷暖房·給湯設備の実態とエネルギ消費量, 空 気調和・衛生工学会論文集, No. 12, pp. $67-80,1980.2$.

12）尾島俊雄, 增田康広:住宅におけるエネルギ消費実態調查 第5 報 エネルギ 消費実態に関する全国調售 (3)エネルギ消費量の回㸟分析と用途構成, 空気調 和・衛生工学会論文集, No. 16, pp. 1-10，1981.6.

13) 石田建一: 戸建住宅のエ㳊ルギー消費量, 日本建築学会計画系論文集, 第501 号, pp. 29-36, 1997. 11

14）澤地孝男，坊垣和明，吉野博，鈴木囊三，赤林伸一，井上隆，大野秀夫，松原 斎樹, 林徽夫, 森田大:用途別エネルギー消費量原単位の算出と推定式の作成 全国的調查に基つく住宅のエネルギー消費とライフスタイルに関する研究 (第 1 報)，日本建築学会計画系論文集，第 462 号, pp. 41-48, 1994. 8.

15) 三浦秀一:全国における住宅の用途別エネルギー消費と地域特性に関する研究， 日本建築学会計画系論文集，第 510 号, pp. 77-83, 1998. 8.

16) 濱田靖弘，中村真人，落莏澄，村越千春，鶴崎敬大，横尾美雪，成田涼子，瞗 原亮，長倉香織，横山真太郎: 札幌における家庭用エネルギー消费量とその季 時別変動に関する実測と評価, 空気調和·衛生工学会論文集, No. 82, pp. 2937, 2001.7 .

17）足立直之, 赤林伸一, 吉野博, 真保聡裕, 坊垣和明, 澤地孝男 : 住宅における エネルギー消費是と住まい方に関する実態調査 新潟市におけるエネルギー需 要構造に関寸る研究 その1, 日本建築学会計画系論文集, 第465号, pp. 4959, 1994. 11.

18) 木村建一, 宿谷昌則, 染藤政文, 野原文男: 独立住宅におけるエネルギー消費 量の実態調查 その1 調査概要と全エネルギ一消費量について, 日本建築学 会大会学術講演梗概集環境工学 II, pp. 469-470，1980.9.

19）(財) 日本エネルギー経済研究所:ライフスタイルとエネルギー消費一省エネル ギーへの一考察一, pp. 71-73， 1995.4.

20 ) 経済企画庁調查局絠 : 平成 12 年版家計消費の動向, 2000.7

21) 東京ガス株式会社 都市生活研究所 : TOKYO 2001-21世紀の人とくらし一, pp. 20-26, 1990. 11 .

22）田中俊彦, 鹿又信一, 高偉俊, 洪元和, 尾島俊雄 : DSMにおけるエネルギ一供 給システムに関する研究 その1住宅における用途別のエネルキー消費特性, 日本建築学会大会学術講演梗概集環境工学 II , pp. 201-202, 1996.9.

23）小坂信二，木村洋，石田建一，太田昭夫:住宅用エネルギー消費量実態調查そ の6)家電·住設機器の消費電力量調查, 日本建築学会大会学術講演梗概集環境 工学 II, pp. 1485-1486, 1993. 9 .

24）田中昭雄, 荒木田好之, 村越千春, 中上英俊: 家電製品の待機時消費電力量の 実測, エネルギー・資源学会第13回エネルギーシステム・経済コンファレン 又講演論文集, pp. 231-236，1997.1.

25) 鶴崎敬大, 村越千春, 横尾美雪, 中上英俊: 北海道における家庭用エネルギー 消費実測および分析(その1)，エネルギー・資源学会第16回エネルキーシス テム・経済・環境コンファレンス講演論文集，pp. 417-422，2000.1.

26) 大橋博之, 田中昭雄, 中上英俊: 家庭における待機時消費電力の実態調查, エ ネルギー・资源学会 第17回エネルギーシステム・経済・環境コンファレン 又講演論文集, pp. 209-214, 2001.1.

27) 源城かほり, 田辺新一: 住宅における電気機器の所有状況に関する調查, 第21 回人間－生活環境系シンポジウム，pp. 139-142，1997. 12.

（2002年 7 月 10 日原稿受理， 2002 年 12 月 12 日採用決定） 